\title{
Environmental Considerations in Procurement Decisions: A
}

\section{Literature Review}

\author{
Ama Amponsah Appiagyei ${ }^{1}$, Joshua Ayarkwa ${ }^{1} \&$ Kofi Agyekum ${ }^{1 *}$ \\ ${ }^{1}$ Department of Building Technology, Kwame Nkrumah University of Science and Technology, \\ Kumasi, Ghana \\ ${ }^{*}$ Kofi Agyekum, E-mail: agyekum.kofi1@gmail.com
}

\begin{abstract}
Public organizations have the potential influence of procuring environmentally preferable products because such organizations are often the biggest customers within a country. Public organizations are required to take environmental considerations in all phases of the procurement process. The need to improve organizational efficiency, reduce waste, overcome supply chain risk, and achieve competitive positions have made companies to start considering environmental issues from a competitive point of view. Procuring organizations are more seriously involved in designing and implementing sustainable procurement policies by focusing on how environmental issues can be integrated in the procurement process activities. However, a clear understanding of environmental considerations and how it can be applied to the procurement process is still lacking, especially in a developing country like Ghana. This paper is a literature review which seeks to examine the environmental requirements applied in the procurement of goods in order to enhance sustainable public procurement in a developing country like Ghana.
\end{abstract}

\section{Keywords}

environmental considerations, sustainable procurement, public procurement

\section{Introduction}

Procurement is the process of acquiring goods, works and services, covering both acquisitions from third parties. It involves option appraisal and the critical "make or buy" decision which may result in the provision of goods and services in appropriate circumstances (Public Procurement Board, 2003). Previous estimates suggest that between 8 to 25 percent of the Gross Domestic Product (GDP) of Organization for Economic Co-operation and Development (OECD) countries and 16 percent of European Union (EU) GDPs were attributed to government purchases of goods or services (Afonso et al., 2005; OECD, 2009).

Although a wide range of issues have been addressed in public procurement research, two major themes have emerged in existing research. The first theme explores the impacts of public procurement on the pattern of economic activity, with a particular focus on the tendency of public procurement to 
favour relatively local companies over foreign suppliers (Laffont \& Tirole, 1991; Tigner, 1991; Vagstad, 1995; Brulhart \& Trionfetti, 2004). In the case of US, "buy American" policies, these tendencies are institutionalized (Vagstad, 1995). The second theme examines the role that government procurement can play as a stimuli for innovative activities among companies within a region. Public procurement has been at the centre of recent discussions on innovation policy on both European and national levels (Aho et al., 2006). This theme is consistent with research in the private sector that has shown how value chain activities affect innovation. For example, within the value chain, procurement activities are associated with greater product quality and innovation (Prajogo et al., 2008).

This study reviews literature related to the concept of public procurement, the nature of public procurement systems before the reforms in Ghana and the situation after the reformation. It continues with literature on the development of sustainable public procurement, the drivers of sustainability, environmental factors in the public procurement system, the barriers to sustainable procurement and the potential ways to implement sustainable procurement in an organization.

\section{Research Methodology}

A two-stage methodology was conducted to achieve the research aim; they are as follows:

\subsection{Stage 1-Identifying the Relevant Literature Material}

The Literature review process started by looking into primary and secondary sources. The primary sources included conferences, journals, articles, theses, government reports, etc. The secondary sources included text books and trade journals. The top journals that were reviewed in the search are: i) Journal of Cleaner Production, ii) Journal for European Environmental \& Planning Law, iii) International Journal of Public Sector Management, iv) International Journal of Science and Research, v) Journal of Supply Chain Management, vi) Journal of Public Procurement among others. These journals were selected as they often publish scholarly papers in the field of sustainable public procurement.

Reports from Department for Environment Food and Rural Affairs (DEFRA UK), Fair trade Foundation, Charted Institute of Purchasing and Supply and World Bank were also covered as they comprehensively and frequently publish up-to-date information. As a result a total number of 96 procurement articles were identified and for the purpose of this paper, such references were selected as they fit the aim.

\subsection{Stage 2-Critical Review of Relevant Literature}

The main topics that were reviewed in this research are Nature of Ghana's procurement systems, Sustainability and public procurement, Sustainable procurement policy framework around the world, drivers of sustainability, integrating sustainability in procurement decisions, environmental factors in sustainable procurement practice, barriers to sustainable procurement and strategies for successful sustainable procurement. These topics were selected on the basis of previous literature in related fields and their link with the purpose of the study. More specifically the work of Walker and Brammer (2009), McCrudden (2004), Preuss (2011) and Bratt et al. (2013) were reviewed. 
The author critically reviewed the articles and systematically analysed the information with the view to identify similarities in the findings of previous writers, differences of statements made and criticisms made by previous writers.

\section{Literature Review}

\subsection{Nature of Ghana's Procurement Reforms}

Prior to the enactment of the Public Procurement Act, 2003 (Act, p. 663), Ghana National Procurement Agency (GNPA) and Ghana Supply Company Limited (GSCL) were the main agents that procured all public goods for the government since there was no comprehensive procurement guidance (Verhage et al., 2002; Anvuur \& Kumaraswamy, 2006). These bodies purchased goods and services on behalf of public entities.

According to PUFMARP (1996), the procurement system in Ghana has: (1) No comprehensive public procurement policy; (2) No central body with technical expertise to oversee/regulate sound procurement practice; (3) No comprehensive legal regime to safeguard public procurement; (4) Absence of clearly defined roles, responsibilities and authority for procurement entities; (5) No rules and regulations to guide, direct, train and monitor public procurement; (6) National Procurement Agency (NPA) and Supply Company Ltd procure on behalf of government for Procurement Entities; (7) No independent appeals process to address complaints from aggrieved tenderers; (8) No authority to dispose of public assets; and (9) No independent procurement auditing and monitoring function. Since there was no comprehensive legal regime and a central body with the responsibility of harmonizing procurement process in the country, more and more sector ministries such as the Ministry Of Health $(\mathrm{MOH})$ decided to implement their own procurement system. Traditional procurement methods were used for public works with provisions for compulsory registration and classification of suppliers and contractors administered by the Ministry of Water Resources, Works and Housing. Since 1999, the Ministry of Finance has been working on the development of a national Procurement Code using the achievements in procurement at the Ministry of Health as an example to largely regulate procurement through the issuance of circulars. This complements a set of procedures that evolves from conventions that are connected with procurement control by the Ministry.

Major or complex contracts that were financed by the government through architectural consultancy services and project supervision were assigned to the Architectural and Engineering Services Limited (AESL) on single basis without recourse to fair competition (World Bank, 1996). These uncoordinated and unregulated systems of procurement were the consequences of poor procurement situations that led to the much-acclaimed reform of public procurement practices to instill trust and confidence in the public and the donor community.

Ghana's public procurement reform is part of a number of reform agendas embarked upon by the government with the aim of improving public financial management and assisting in generating budgetary savings. The objectives are to streamline the system of procurement for goods, works and 
services for national development; to harmonize local and international laws regarding procurement; foster competition, make efficient use of national resources, ensure transparency and accountability and provide value for money (Ministry of Finance, 2009).

The World Bank (1996) identified some major flaws in Ghana's public procurement system which included a loose legal framework, lack of codified procedures and regulations, the weak capacity of procurement staff, huge expenditure, and unclear institutional and organizational arrangements for processing procurement and decision making in awarding contracts. This has led to the enactment by Parliament, of the PPA 663 in 2003. The Act provides a comprehensive public procurement mechanism. For example, Part I stresses the setting up of a Public Procurement Board, which is the central body in charge of policy formulation on procurement with oversight responsibility for the process. Part II specifies the establishment of a Tender Committee and Review Board.

The former ensures compliance with the Act by providing one-stop procurement decisions for approvals and awards of contracts to certain predefined value thresholds and referrals to the Review Board for approval (Clause, p. 17). Parts IV and V stipulate the methods of procurement, procedures for preparing tender packages, evaluating tenders and awarding contracts (Clause, pp. 34-40). Clause 50 stipulates that the lowest bidder shall be considered successful with the tender price ascertained on the basis of the criteria specified.

\subsection{Sustainable Public Procurement}

The concept of Sustainable Procurement (SP) originally surfaced at the UN World Summit on Sustainable Development in Johannesburg in 2002. Borland (2009) posits that sustainable procurement include environmental, social/cultural, planetary and financial considerations. Sustainable Procurement processes therefore should result in the balancing of economic development, social development and environmental protection against business needs.

Sustainable Public Procurement is therefore a process whereby public organizations meet their needs for goods, services and works in a way that achieve value for money in addition to minimizing damage to the environment and ensuring social safeguards (PPA, 2012). Unlike traditional procurement which focuses on value for money considerations only, sustainable procurement involves achieving value for money on a whole life basis with the goal of reducing possible adverse effects (Preuss, 2009; Walker \& Brammer, 2009). Adjei (2010) posits that SPP considers the environmental, social and economic consequences of: design, non-renewable material use, manufacture and production methods, logistics, service delivery, use, operation, maintenance, reuse, recycling options, disposal, and suppliers' capabilities to address these consequences. It upholds the principles of transparency, fairness (to both the supplier and society), long term economy, and accountability (from purchaser and supplier). The rationale behind sustainable public procurement is not only the fact that governments can use their purchasing power as an economic incentive for sustainable development in general, and for sustainable consumption and production in particular, but also that the option of sustainable public procurement puts the governments to the test in achieving sustainable development (Steurer et al., 2007). 


\subsection{Sustainable Procurement (SP) Policy Frameworks around the World}

The best way to ensure sustainable procurement is to develop a framework that embeds sustainability issues in the procurement process. Over the years, sustainable procurement policy framework have emerged in different countries and regions, especially in the developed world. This section discusses some of the policy frameworks worldwide and compares them to what have been done in Ghanaso far. In the UK, policy context concerning public procurement is based on a set of guiding principles, including transparency, competitiveness, accountability, efficiency, legality, and integrity, that have the ultimate aim of supporting the delivery of "best value for money" in public procurement (Her Majesty's Treasury, 2000). Best value for money gives focus to public entities to take into considerations social and environmental objectives in their procurement practices. This was recognized by the UK Government in its 2005 Sustainable Development Strategy, and an SP Task Force was established in 2005 to develop SP guidance. The UK Government stated its goal to be amongst the leaders in the EU on SP by 2009 (Department for Environment, Food \& Rural Affairs, 2007).

Public procurement in the EU is guided by national policy frameworks, coupled with an overarching EU policy framework that is designed to open up the EU's public procurement market to competition, outlawing "buy national" policies and promoting the free movement of goods and services. One study examined the state of development of national action plans regarding green or SP in the EU (Steurer et al., 2007). Of the 27EU member states, their analysis showed that only a third of governments had adopted an action plan concerning SP as at April 2007, with a further five countries having a draft policy concerning SP that had not yet been adopted. Countries with relatively well-developed plans included. The Netherlands, Denmark, and the UK, while countries still in the early stages of developing national action plans included Germany, Greece, The Slovak Republic and Malta. The emphasis of SP policy in the EU is environmental rather than social in character. For example, in Italy there is a mandate that 30 per cent of goods purchased by public administration comply with ecological criteria. Denmark, France. The Netherlands, and the UK have public procurement policies specifically for wood and paper products, and in Belgium there is an initiative to ensure that 50 percent of government vehicles comply with specific environmental criteria.

SP policy frameworks in the USA have, alongside environmental purchasing, a particular emphasis on avoiding discrimination and providing equal opportunities, in line with the constitution (McCrudden, 2004). These issues have most clearly been crystallized in the development of federal policies that promote procurement from women and minority owned businesses with some emphasis on purchasing from indigenous people.

Canadian federal government procurement policies emphasize similar economically oriented aspects of purchasing as those found in Europe including mandates concerning promotion of competition and value for money. The Canadian federal government founded the Office of Greening Government Operations (OGGO) in 2005, which developed its Policy on Green Procurement in 2006. Through this policy, all government bodies are required to formulate green procurement targets and all personnel 
responsible for procurement need to be trained in green procurement. The OGGO provides purchasers with a decision making toolkit and a checklist on their web site to encourage them to consider sustainability.

In Japan, a law on green purchasing was passed in 2001 that compelled all government bodies to develop and implement green purchasing policy (European Coalition for Corporate Justice, 2007). In South Africa, public procurement was seen as an important policy lever in the post-apartheid world. Specifically, the black economic empowerment initiative encouraged the public sector to buy from black-owned businesses in order to redress the economic advantages of white-owned businesses attributable to apartheid (Department of Trade and Industry South Africa, 2003). In Australia, local businesses were supported by state-based schemes such as "Buy Queensland" and a SP framework was developed to aid buyers.

In Ghana, the government recognizes that a more effective procurement system is critical to achieve the country's growth and poverty reduction goals and has fundamentally reformed its procurement systems (Roos, 2013). Moving forward, Ghana has been an active member of international procurement networks such as the Task Force on Procurement and the Marrakech Taskforce on Sustainable Procurement. In 2010, the Government of Ghana decided to embark on SPP (PPA, 2012; OECD, 2011d; PPA, 2011). SPP in Ghana is implemented through the Swiss-Ghana Sustainable Public Procurement (SPP) Project, a three-year project being implemented by PPA and financed by the Swiss Government with a USD 2.7 million grant. Both legal compliance with the SPP implementation is considered pivotal for the institutionalization of SPP. The SPP process is modeled in accordance with the MTF Approach to SPP and addresses the three dimensions of sustainability, i.e., the economic, social and environmental dimensions.

In summary, a range of aspects of sustainability are the subject of explicit procurement policies around the world. The environmental aspects of sustainability seem well represented in policy frameworks within Europe and hence the need for African context.

\subsection{Drivers of Sustainability}

The drivers of sustainable procurement encompass social, economic and environmental factors. The integration of social and environmental criteria into public procuring activities is influenced by both internal and external actors (Walker et al., 2008; Brammer \& Walker, 2009). Brammer and Walker (2009) assess the facilitators and influences that affect SPP practices in their international comparison. They found out that the primary reason to implement SPP practices is the national policy context. Brammer and Walker (2009) state that "where SP policy and legislation exists, it appears to be widely implemented. However, where directives are more voluntary in character, competing necessities and priorities often dominate". Thus, the political integration of the concept seems to be an important determinant for the success of SPP measures. Mont and Leire (2009) identified stakeholder influence, media and NGO attention as the main drivers for SPP besides internal influence through organizational values and employees' concern. This is supported by Walker et al. (2008) who regard public pressure 
and stakeholders as the most definite influence, such as through campaigners, NGOs or green pressure groups. According to Chartered Institute of Procurement and Supply (2012) there are different types of support factors for sustainable procurement. Drivers of sustainable procurement are forces which create positive pressure to develop and implement sustainable procurement strategies by creating opportunities or threats which must be addressed by the procurement function in any organization. These drivers must enable the creation of conditions favorable for the effective and efficient introduction, implementation and acceptance of sustainable procurement processes and practices.

The driving forces of sustainable procurement or reasons for increased focus on sustainability includes: increased pressure for greater corporate responsibility and accountability (John et al., 2010); possible damage to the environment throughout the production processes (Masaaki \& Michael, 2008); and growing awareness of the operational, financial and reputational risks of unsustainable business practices (Boaz \& Shimeon, 2008). Factors such as scarcity of resources, legislation and legal frameworks, stakeholder pressure and concerns together with reputational risk and opportunities are also likely to drive public organizational measures for sustainable procurement.

John (1998) argues that drivers of sustainable procurement come into play when public organizations deliberate on important issues such as: whether the public organization is complying with environmental protection and sustainable use of available resources; whether its procurement function is enhancing the economic security of the organization by adding value, controlling costs and securing continuity of supply without negative social and environmental impact; and whether meeting present needs of the organization and its stakeholder compromise the ability to continue doing so in the future.

\subsection{Integrating Sustainability into Procurement Decisions}

In order to help integrate sustainability into procurement decision, various public authorities in the EU base their SPP efforts on certification, meaning that suppliers have to use labels and be certified by third-party organizations like Fairtrade or Fair Wear (Mont \& Leire, 2009). A wide range of instruments have been established, especially, the rise of voluntary standards and criteria can be mentioned (Preuss, 2009; Mont \& Leire, 2009). Certain criteria are developed that "suppliers need to fulfil if they want to sell their products to an organization" (Mont \& Leire, 2009).

Krause et al. (2009) in their study argued that an organization is no more sustainable than its supply chain. Procurement is in a central position when it comes to creating sustainable development in a supply chain. There are several means to implement sustainability in procurement decisions. Implementation of a framework policy or an action plan or setting common commitments for the operations are common means among several others (Sustainable Procurement Guide, 2013). Sustainability should be integrated in the early stages of purchasing and considered carefully throughout the process. Whenever planning to make a purchase, there are several sustainability issues that should be considered. The first one is simply avoiding unnecessary purchasing by evaluating the need for the product or service. Other issues include taking into consideration the pollution, emissions and water and energy consumption during the product's whole life cycle. A product with least negative 
social and environmental impact should be preferred. When it comes to supply chains and for instance outsourcing, it is also crucial to verify that the suppliers actually comply with the existing standards and regulations. In order to enhance environmental sustainability, Krause et al. (2009) suggest that attention should be drawn to issues such as reduction of material usage and utilization of recyclables when purchasing leverage items.

A study by Appiah et al. (2014) showed that in Ghana the integration only occurs as and when the procurer wishes to since no clear cut dictates and requirements are spelt out in the Public procurement Act (Act p. 663) other than loosely stated, and overly glossed over statements concerning social and environmental considerations.

\subsection{Environmental Factors in Sustainable Procurement Practices}

An organization must consider various elements when deciding on a facility location and logistic purchases (Patrick, 2001). Moving forward, designs should be made in a manner that minimizes energy use, reduces noise and pollution and make it more efficient to produce the products needed. Environmental drivers for sustainable procurement steers the organization towards efficient and sustainable use of available resources (CIPS, 2012). As such, organizations must promote the use of renewable sources of input and put great considerations on how those resources are used in order to guarantee availability of those resources in the future (Lyson \& Farrington, 2012). Paul et al. (2008) stated that environmental considerations help the organization to make specification for green products through selecting, management and development of suppliers with environmental capabilities and commitments. Paul et al. (2008) further indicated that there is also deliberate effort put in place to reduce waste of resources throughout the sourcing cycle, minimization of pollution, waste and emission and recycling or safe disposal of products at end of life. Environmental drivers of sustainability seek to minimize any negative environmental impacts of goods and services purchased, across their life cycles from raw material extraction to their end of life. Warner and Ryall (2001) found out in a study that many local authorities integrated environmental considerations into their procurement policies and these initiatives were only rated as moderately successful, with higher costs of green products emerging as the most commonly cited barrier.

However, the laws governing procurement in Ghana have not enforced that all procurement transactions are to fulfill sustainability goals. Section 59 of Ghana's Public Procurement Act, 2003 (Act, p. 663) includes some economic and social sustainability issues. The emphasis as outlined in Section 59 is on the economic aspect. There are few social considerations, with virtually no consideration on environmental issues. The environmental aspect, though not captured in the law, has disconnected regulations on issues like Energy Efficiency Standards, Pesticides Control and Management, reduction in greenhouse gas emissions, Forest and Wildlife management, Mining and others.

\subsection{Reasons Why Organizations Engage in Sustainable Procurement Practices}

The attention of world leaders is now more than focused on issues to do with climate change, the ever increasing gap between wealthy nations and developing countries and environmental degradation. With 
rising interest in sustainability, the responsibility of the consumer to ensure the adherence of social and environmental standards on the production sites has become a hot topic (McCrudden, 2009).

Furthermore, SPP can attribute to closing the often existing gap between aspiration to act sustainably and the actual practice of organizations (McCrudden, 2009). According to McCrudden (2009), the thought of sustainability is theoretically on the rise, yet the translation into action lags behind because many organizations aspire to meet environmental and social standards but the necessary actions are often missing. McCrudden (2004) refers to the power of the purse and states that public authorities have the budgets and power to change whole markets. If public procurement takes sustainability into account, suppliers are influenced to act accordingly and to even access markets that did not exist previously (Bratt et al., 2013; Burja, 2009; Erdmenger, 2003).

Besides direct influences on suppliers, the engagement in SPP generates indirect opportunities for public authorities to influence market participants. Numerous scholars emphasize the exemplary function that governments can have on corporations through embedding sustainability into their own strategy (Steurer, 2011; Nijaki \& Worrel, 2010; Preuss, 2009). Through their own action, public authorities set example and encourage private actors to include the dimension of sustainability into their actions. McCrudden (2009) stated that "in order for corporations to make sustainable improvements in their social and environmental performances, the role of government must change". In addition to these external reasons to engage in SPP efforts, internal goals can also lead to the implementation of SPP (Nijaki \& Worrel, 2010). Day (2005), the Secretary-General of the European Commission, argues that the combination of external and internal advantages of SPP is possible. Through SPP, more efficient use of energy and natural resources, and strategies to cut the amount of waste generated, can save the taxpayer some money. It can help the EU reach more sustainable production and consumption patterns, achieve economic growth without environmental damage, and meet additional sustainable development goals (Day, 2005).

For McCrudden (2009), there is another reason for public authorities to actively use SPP in their sustainability strategies: the embedding of environmental and social concerns into public policies will secure legitimacy. The state is seen as a conscious actor in the market that takes on his responsibility as a caretaker (McCrudden, 2009). Through the use of SPP, the state can act responsibly beyond its own state boundaries and also act as a caretaker for indirectly affected parts of society.

\subsection{Barriers to the Adoption of Sustainable Procurement Practices}

The adoption of sustainable procurement practices will certainly not be without challenges. There will be hurdles to be surmounted. The most common barriers obstacles outlined by Offei (2014) are: 1) Obscure definition of sustainable procurement; 2) Limited motivation to procurement officers; 3) Cost in complying to sustainable procurement standards; 4) Inadequate resources to integrate environmental factors in procurement practice; 5) Difficulty in changing strategies in public sectors; 6) Lack of knowledge in sustainable procurement standards; and 7) Decentralization nature to procurement practice. 


\subsection{Strategies for Successful Sustainable Procurement}

Government procurement therefore needs to consider sustainability issues as it is the only way that it can be sure to offer real value for money over a longer term without compromising environmental and social responsibilities (Adjei, 2010). This would ensure that development targets are achieved through the acquisition of goods, works and services without much damage to society and the environment. A study by Offei (2014) outlined strategies that can enhance successful implementation of sustainable procurement, they are described below:

1) Integration of sustainable procurement into existing practices: It is important to integrate strategies that will enhance sustainable procurement practices. Since time and resources are often limited, SP initiatives have to be incorporated easily into the responsibilities of purchasers (Fitzgerald et al., 2007). In order to ensure continuous flow in the supply chain, sustainability can be incorporated smoothly through training programs already undertaken by organizations.

2) Making the business case to include sustainable procurement requirements: Organizations have to find areas where profit can be made for particular initiatives and the profit utilized in sustainable initiatives (Gattiker et al., 2008). This will reduce the cost barrier. This can further be achieved if the procurement system is regarded as a whole rather than separated interactions, Lyons (2002) posits it as "systems thinking".

3) Utilize reverse logistics to monitor the application of sustainable procurement: Reverse logistics is for all operations related to the reuse of products and materials. It is "the process of moving goods from their typical final destination for the purpose of capturing value, or proper disposal". This system is rarely used or underutilized in most organizations (Zsidisin \& Siferd, 2001), even though it leads to a lot of cost saving son disposal, transportation and the likes (Walton et al., 1998).

4) The need to conduct supplier's assessment: According to Gattiker et al. (2008), supplier assessment is getting suppliers to alter their internal practices or offer more sustainably produced products. Some of the methods of assessing suppliers include score cards, questionnaires, audits, and consistent standards (Lippman, 1999). This can enhance sustainable practices by making suppliers aware of the inclusion of environmental criteria in tender evaluations, in so doing suppliers will match up.

5) The need to engage suppliers for sustainable procurement: One of the ways to enhance sustainable practices is to engage suppliers. Suppliers must be willing to establish a good relationship in order to pursue sustainability initiatives (Lyons, 2000). When suppliers are willing, collaboration and sharing of sustainability goals, objectives, and strategies can begin to take place (Lippman, 1999). When supplier needs are considered in this process, they are often more willing to engage with an organization's sustainability objectives and work collaboratively (Fitzgerald et al., 2007). 


\section{Conclusions}

Sustainable procurement has received considerable attention and discussion in policy circles around the world, especially the developed countries. But little is known about its acceptance in a developing countries like Ghana. In this paper a brief theoretical discussion has been presented on sustainable procurement with a focus on its meaning and drivers, especially environmental and practical implications for the procurement process. It has identified research trends in sustainable procurement which will allow industrial practitioners to include environmental considerations in their procurement decisions. The main conclusion from this paper is that, there is the need to protect the environment and this can be achieved through implementing sustainability in our procurement decisions. This will ensure long-term value for money and protection of lives. There seem to be barriers in applying environmental considerations in public organizations. This is partly due to the perceived associated risks and attitudes towards change. In order for public organizations to be able to meet this innovation, there should be a collaborative effort from both government and top management.

\section{References}

Adjei, A. B. (2010). Sustainable Public Procurement: A new approach to good governance. International Public Procurement Conference.

Afonso, A., Schuknecht, L., \& Tanzi, V. (2005). Public sector efficiency: An international comparison. Public Choice, 123, 321-347.

Aho, E., Cornu, J., Georghiu, L., \& Subira, A. (2006). Creating an innovative Europe. Aho Group Report, European Communities, Belgium.

Appiah, S. C. Y., Abubakari, M., \& Offei, E. (2014). Integrating environmental \& social considerations into public procurement practice in Ghana. The International Journal of Humanities \& Social studies, 2(6).

Boaz, R., \& Shimeon, P. (2008). Focused Operations Management. New Jersey: John Wiley \& Sons.

Borland, H. (2009). Conceptualizing global strategic sustainability and corporate transformational change. International Marketing Review, 26(4/5).

Bratt, C., Hallstedt, S., Robèrt, K.-H., Broman, G., \& Oldmark, J. (2013). Assessment of criteria development for public procurement from a strategic sustainability perspective. Journal of Cleaner Production, 52, 309-316.

Brulhart, M., \& Trionfetti, F. (2004). Public expenditure, international specialization and agglomeration. European Economic Review, 48(4), 851-881.

Burja, A. (2009). Using Green Public Procurement (GPP) for sustainable consumption and production. Journal for European Environmental \& Planning Law, 6(3), 319-338.

Chartered Institute of Purchasing \& Supply. (2012). Sustainability in Supply Chains. Lincolnshire: ProfexPublishing.

Chartered Institute of Purchasing \& Supply. (2012). Supply Chain Diligence. Lincolnshire: Profex Published by SCHOLINK INC. 
Publishing.

Day, C. (2005). Buying green: The crucial role of public authorities. Local Environment, 10(2), 201-209.

Department for Environment Food \& Rural Affairs. (2006). Procuring the Future-The Sustainable Procurement. Task Force National Action Plan, DEFRA, London.

Department for Environment Food \& Rural Affairs. (2007). Securing the Future: UK Government Sustainable Procurement Action Plan Incorporating the Government Response to the Report of the Sustainable Procurement Task Force. DEFRA, London.

Department for Environment Food \& Rural Affairs. (2007). UK Government Sustainable Procurement Action Plan, DEFRA (Department for Environment, Food and Rural Affairs).

Department of Trade \& Industry South Africa. (2003). South Africa's Economic Transformation: A Strategy for Broad-Based Black Economic Empowerment. Department of Trade and Industry South Africa, Cape Town.

Erdmenger, C. (2003). Buying into the Environment: Experiences, Opportunities and Potential for Eco-procurement. Greenleaf, Sheffield.

European Coalition for Corporate Justice. (2007). Sustainable Procurement in the European Union Proposals and Recommendations to the European Commission and the European Parliament. European Coalition for Corporate Justice, Brussels.

Fair Trade Foundation. (2002). FairTrade Towns Initiative, FairTrade Foundation. London. Retrieved from http://www.fairtrade.org.uk/includes/documents/cm_docs/2008/f/fairtrade-towns.pdf

Fitzgerald, S. E. (2007). Strategies for Sustainable Supply Chain Management: Supplier framework and empirical example. Supply Chain Management: An International Journal, 12(4).

Gattiker, T. F. (2008). Supply Management's strategic Role in Environmental Practices. Center for Advanced Purchasing Studies.

Ghana Public Procurement Act. (2003). Republic of Ghana: Accra Ghana Publishing Corporation.

Her Majesty's Treasury. (2000). Government accounting 2000. Retrieved from http://www.Governmentaccounting.gov.uk

http://www.ungm.org/sustainableprocurement/

John, A. P. II., Richard, B. R. Jr., \& Amita, M. (2010). Strategic Management (10th ed.). New York: McGraw Hill.

John, E. (1998). Accounting for the Triple Bottom Line. Measuring Business Excellence, 2(3), 18-22.

Krause, D., Vachon, S., \& Klassen, R. (2009). Special topic forum on sustainable supply chain management: Introduction and reflections on the role of purchasing management. Journal of Supply Chain Management, 45(4), 18-25.

Laffont, J. J., \& Tirole, J. (1991). Auction design and favoritism. International Journal of Industrial Organization, 9, 9-42.

Lippman, S. (1999). Supply chain environmental management: Elements for success. Corporate. 
Lyons, J. B. (2002). The learning environment: Do school facilities really affect a child's education? Learning by Design, 11, 10-13.

Lysons, K., \& Farrington, B. (2012). Purchasing and Supply Chain Management (8th ed.). Pearson Education Limited. Essex.

Masaaki, K., \& Michael, J. M. (2008). Global Supply Chain Management, 2.

McCrudden, C. (2004). Using public procurement to achieve social outcomes, Natural Resources Forum, 28(4), 257-267.

Mont, O., \& Leire, C. (2009). Socially responsible purchasing in supply chains: Drivers and barriers in Sweden. Social Responsibility Journal, 5(3), 388-407.

Nijaki, L. K., \& Worrel, G. (2010). Procurement for sustainable local economic development. International Journal of Public Sector Management, 25(2), 133-153.

OECD. (2009). OECD in Figures, OECD, Paris.

Offei, E. (2014). Integrating environmental and social considerations into public work procurement in Ghana. Thesis submitted to the School of Graduate Studies, K.N.U.S.T.

Paul, C., Richard, L., Benn, L., \& Brian, S. (2008). Strategic Supply Chain Management. Essex: Prentice Hall.

Prajogo, D. I., McDermott, P., \& Goh, M. (2008). Impact of value chain activities on quality and innovation. International Journal of Operations \& Production Management, 28(7), 615-635.

Preuss, L. (2009). Addressing sustainable development through public procurement: The case of local government. Supply Chain Management: An International Journal, 14(3).

PPA E-Bulletin Report. (2012). Pursuing the sustainable public procurement (spp) agenda. Jul-Aug, 3(4). Ghana.

Roos, R. (2013). Sustainable Public Procurement in LICs. Implications for the Ongoing World Bank Procurement Review. Federal Ministry for Economic Cooperation and Development. GIZ.

Steurer, R. (2011). Soft Instruments, Few Networks: How "New Governance" Materializes. In Public Policies on Corporate Social Responsibility across Europe (Vol. 21, No. 4, pp. 270-290).

Steurer, R., Berger, G., Konrad, A., \& Martinuzzi, A. (2007). Sustainable public procurement in EU member states: Overview of government initiatives and selected cases. Final Report to the EU High-Level Group on CSR, European Commission, Brussels.

Sustainable Procurement Guide. (2013). Department of Sustainability, Environment, Water, Population and Communities. Australian Government. Retrieved from http://www.environment.gov.au/system/files/resources/7b8df2bd-3bb9-49cc-b417-5f2eb6e0ce37/f iles/susta

Tigner, B. (1991). EC policy: Opening the bidding. International Management, 46(6), 46-49.

Vagstad, S. (1995). Promoting fair competition in public procurement. Journal of Public Economics, 58(2), 283-307.

Walker, H., \& Brammer, S. (2009). Sustainable procurement in the United Kingdom public sector. Published by SCHOLINK INC. 
Supply Chain Management - An International Journal, 14(2), 128-137.

Walker, H., Di Sisto, L., \& McBain, D. (2008). Drivers and barriers to environmental supply chain management practices: Lessons from the public and private sectors. Journal of Purchasing and Supply Management, 14(1), 69-85.

Warner, K. E., \& Ryall, C. (2001). Greener purchasing activities within UK local authorities. Eco management and Auditing, 8(1).

World Bank. (1996). Ghana 1996 Country Procurement Assessement Report for Ghana. Washington, DC. The World Bank.

World Bank. (2003). Ghana 2003 Country Procurement Assessment Report. Washington, DC: Ghana Country Department. The World Bank.

Zsidisin, G. A., \& Siferd, S. P. (2001). Environmental purchasing: A framework for theory development. European Journal of Purchasing and Supply Management, 7. 